Sveučilište u Zagrebu

mdimkov72@gmail.com

Jelena Marković

Sveučilište u Zagrebu

jelena@ief.hr

\title{
Nostalgija kao (ne)ozbiljna emocija: igre i igračke kao podobjekt nostalgije u svakodnevnim narativnim praksama o djetinjstvu
}

\begin{abstract}
Aвstract: Dimkov Marijana, Marković Jelena, Nostalgija kao (ne)ozbiljna emocija: igre i igračke kao podobjekt nostalgije u svakodnevnim narativnim praksama o djetinjstvu (Nostalgia as [Un]Serious Emotion: Games and Toys in Everyday Narrative Practices about Childhood). "Poznańskie Studia Slawistyczne" 9. Poznań 2015. Publishing House of the Poznań Society for the Advancement of the Arts and Sciences, pp. 223-238. ISSN 2084-3011.

This paper analyzes the contemporary context of nostalgia, recollection and narration of childhood events on the basis of field notes collected by means of different methodological techniques. The narrative quest for the past produces interpretations of past events and experiences and opens the space to the feeling of nostalgia, or nostalgic stories. This paper aims to present a small portion of the captured everyday life in which games and toys appear as any other subobject or pseudoobject of nostalgia, but with a distance from one's own childhood experience. We utilize Donald Braid's approach which opens the space for observing the transmission of oral personal narratives and the transmission of emotions in and through language.
\end{abstract}

KEYwORDS: personal narratives; childhood; nostalgia; games; toys

\section{Uvod}

Proživljena iskustva svakodnevice, koja su uvijek dijelom epizodnog pamćenja, mogu postati dijelom autobiografskog pamćenja, odnosno upamćena jedinstvena i neponovljiva pojedinačna iskustava ${ }^{1}$. Upravo ta

${ }^{1}$ Epizodno pamćenje, koje obuhvaća jedinstvena osobna iskustva, a može se oblikovati jezikom, širi je pojam od autobiografskog pamćenja (Tulving 1972: 218). Epizodno pamćenje 
pojedinačna iskustva čine riznicu uspomena i emocija, koje u trenutku prisjećanja i narativizacije mogu biti praćene osjećajem nostalgije, a ona će nas u ovom prilogu najviše zanimati. Narativna potraga za prošlim proizvodi interpretacije minulih događaja $\mathrm{i}$ iskustava te otvara puteve osjećaju nostalgije, odnosno nostalgičnim pričama koje često funkcioniraju kao spremišta pozitivnih aspekata proživljenih situacija. Sjećanja iz djetinjstva najčešće su prekrivena zaboravom, a i kada nisu, njihove reinterpretacije su dinamični i istraživački prilično teško uhvatljivi procesi jer su uglavnom organski dijelovi svakodnevice. Krhotine iskustva koje pamtimo temporalno su promjenjive kao i načini njihova strukturiranja u priču što katkada može proizvesti njezine nostalgične prizvuke. Stvaranjem narativnih oblika o sebi nastaju i emotivno važne priče obilježene stalnim razaranjem vremenskih kategorija, kao i pozadinska slika o vlastitom ja, obitelji, društvu i kulturi u kojoj živimo (cf. Moran 2002: 156).

Razni su autori nastojali osjećaj nostalgije objasniti i u korelaciji s djetinjstvom (Boym 2001; LeBlanc 1999; Marković 2011; Moran 2002; Stewart 2003). Nostalgija je osjećaj kojim su povezani prošlost i sadašnjost, osobno i kolektivno. Snažna je to i duboka osobna emocija koja se manifestira kao čežnja za vlastitom prošlosti, prošlim vremenima, ljepšim i veselijim životom. S obzirom na uzastopno izmicanje privlačnog objekta nostalgije, teško je odrediti za čime točno postoji stalna čežnja (cf. Marković 2012: 303). Materijalni objekti poput fotografija, igračaka, knjiga, odjeće ili nekih izrazito konzumeristički determiniranih proizvoda, ali i mirisi, okusi i sl. koji su povezani s djetinjstvom, mogu zadobiti neočekivano poseban status u pamćenju i naraciji o njemu. Oni mogu postati okidači uz pomoć kojih se nanovo može prizvati prošlost, ali samo u prisjećajnom i narativnom obliku. Ta je prošlost u nostalgičnim narativima uobličena uz pomoć prisjećajnog i emotivnog sukoba prošlosti i sadašnjosti. Ipak, prošlo vrijeme je neponovljivo i jedino još može postojati kroz tekstualnu reprezentaciju. U nostalgičnim pričama djetinjstvo je primarno definirano

„pohranjuje informacije o temporalno datiranim epizodama ili događajima i temporalnospacijalnim odnosima među tim događajima" (Tulving 1972: 385). Ako epizodno pamćenje ima bitnu ulogu u životu pojedinca, onda se ono naziva autobiografskim pamćenjem i može biti dijelom životne priče ili može biti tematizirano osobnom pripoviješću ili pripoviješću o osobnom iskustvu (više o konceptima životna priča, osobna pripovijest i pripovijest o osobnom iskustvu vidi u Marković 2010b). 
predodžbama o nevinosti, bezbrižnosti i potpunoj odvojenosti djetinjstva od odraslosti, a svako odstupanje od tih predodžbi ujedno potvrđuje status djeteta i djetinjstva u suvremenoj kulturi. Nostalgičnom pričom naglašava se vrijednost ,izgubljenog” vremena ranog iskustva življenja, tražeći u prošlosti vrijednosti koje manjkaju u prostoru sadašnjice. Prolazeći kroz tegobe življene realnosti, preslagujemo krhotine sjećanja i oblikujemo ih u narativne cjeline kojima prenosimo i emocije, čime pridonosimo idealizaciji prošlosti na temelju koje se uspostavljaju vrijednosna mjerila za trenutno bivanje. Naknadno konstruirana priča o djetinjstvu kao ,zlatnom dobu" vlastite ontogeneze stvara nostalgijom upravljanu potrebu za povratkom u djetinjstvo posredstvom priče ili kroz nju.

Ovim radom želimo prikazati jedan mali dio uhvaćene svakodnevice gdje igre i igračke figuriraju kao bilo koji drugi podobjekt ili pseudoobjekt nostalgije, ali sa specifičnim, katkada ironijskim, a katkada „,smrtno ozbiljnim", odmakom od vlastitog dječjeg iskustva. Objekt nostalgije u prikupljenim pripovijestima gotovo je uvijek djetinjstvo kao životno razdoblje, razdoblje koje je za pripovjedača zauvijek završilo (cf. Marković 2012: 314).

\section{Pokoja riječ o metodologiji}

Tijekom osmišljavanja istraživanja te tijekom terenskoga rada nastojale smo slijediti ideju Donalda Braida (1996) koji je promovirao osobit pristup osobnim pripovijestima prema kojemu usporedno promatra, $\mathrm{s}$ jedne strane kako pojedinci smislenim čine i življeno iskustvo i pripovjednu izvedbu tog iskustva, te s druge strane promatra kako iskustvo procesa „slijeđenja” pripovijesti (dakle njezine recepcije) može dovesti do tijeka misli u slušatelja koje naziva iskustvenim značenjem koje uključuje emocionalne svjetove svih sudionika govorne razmjene. Pri tome iskustveno značenje osobne pripovijesti za slušatelja postaje dostupnim resursom za daljnju uporabu. Tim pristupom Braid otvara novi prostor za promatranje ne samo transmisije usmenih pripovijesti o nekom osobnom iskustvu, nego zadire duboko u pitanja relacijske prirode sebstva koje pripovijeda i sebstva kojem se pripovijeda, transmisije emocija u jeziku i kroz njega. 
Metodološki gledano, pristup građi u raznim neformalnim situacijama, odnosno tzv. prirodnom, pripovjedačkom kontekstu, ili barem njemu nalik, teško je ostvariv ideal. Zbog toga je u ovom istraživanju korišteno više metodoloških postupaka i više načina bilježenja građe ${ }^{2}$. Međuljudski susreti i komunikacijske narativne razmjene osigurali su raznovrsnu građu kojoj je zajedničko obilježje prisjećanje djetinjstva i često usporedno emocionalno pripisivanje značenja objektima i aktivnostima, najčešće igrama i igračkama. U pojedinim situacijama razgovori su nalikovali kazivačkim, istraživačkim situacijama, ali katkada su oni bili smješteni u spontano, neplanirano vrijeme svakodnevice. U prigodama neformalnijeg karaktera zadiranja u priče iz razdoblja djetinjstva često nije bilo moguće ciljano i izravno zabilježiti, što je zahtijevalo naknadnu rekonstrukciju i bilježenje. S druge strane, suvremena tehnološka dostignuća poput Skypea omogućila su novi i drukčiji tip komunikacije kojim je moguće trajno arhivirati priče „na daljinu” s osobama koje nisu fizički prisutne na istom prostoru, dok je standardno terensko sredstvo poput diktafona bilo rezervirano za planirani susret s kazivačima.

Iskustvo vlastitog djetinjstva pokazalo se bogatim vrelom narativnih isječaka s nostalgičnim prizvukom. Tijekom zalaženja u tjesnace prošlosti ponekad je bilo potrebno posegnuti za starim predmetima i fotografijama. Fotografirani trenuci iz povijesti jednog djetinjstva pokazuju paradoks trajne prolaznosti i autentičnost sustavno artikuliranog vremena i prostora (cf. Moran 2002: 163).

Autoetnografskim pristupom ${ }^{3}$ građa koja je pohranjena u vlastitim sjećanjima dobila je priliku tekstualizirati se i ujedno dobiti analitički osvrt iz perspektive odmaklog vremena bogatog novim znanjima i iskustvenim kapacitetom.

${ }^{2}$ Građa koja je razmatrana u ovoj raspravi prikupljena je manjim dijelom u razdoblju od 2005. do 2010. godine (Marković), a većim dijelom 2012. godine (Dimkov) različitim metodološkim postupcima. Građa je dijelom naših privatnih arhiva. Pitanje (ne)pohrane, (ne) arhiviranja terenske građe, odnosno njezine javne (ne)dostupnosti (djelomično ili u cijelosti) u kontekstu zaštite sudionika u istraživanju kompleksno je pitanje o kojem je raspravljano na drugom mjestu (Marković 2010a).

${ }^{3} \mathrm{O}$ autoetnografiji vidi više kod: Gulin Zrnić 2006; Hastrup 1992; Okely 1992. 


\section{Zov djetinjstva - sjećanja na svijet igre}

Još jedna priča iz djetinjstva je vezana uz kućicu na drvetu, gdje smo moja družina i ja provodili ljeto, oboružani praćkom te lukom i strijelom u stilu Pocahontas. Borili smo se sa malim šumskim živinama koje su nam stalno kršile red. Mnoga ranjava i izguljena koljena su prouzročena penjanjem na drvo, ali uvijek ih se s nostalgijom sjetim. Djetinjstvo je stvarno bio najljepši period na svijetu, bez brige i pameti, jedino je bilo važno igrati se (autorica: dvadesetčetverogodišnjakinja).

Iako je igra već odavna prepoznata kao cjeloživotna aktivnost, od dojenačke dobi do smrti (Huizinga 1970; Winnicott 2004), ona se u svakodnevici često postavlja kao suprotnost radu koji je aktivnost koja je namijenjena isključivo odraslima. Igru se često želi vidjeti kao pojam koji definira djetinjstvo kao bezbrižno, nevino, slobodno. Međutim, igra se proteže u kreativno življenje i cjelokupni kulturni život čovjeka te nije isključivo rezervirana za razdoblje djetinjstva (cf. Winnicott 2004). Ova kontradiktornost predodžbi i prirode igre čini ju još privlačnijom i potentnijom za prisjećajne i pripovjedne aktivnosti koje su istovremeno i proizvod nostalgične čežnje za trenucima trajanja igre i koji nostalgičnu čežnju proizvode. Svijet igre po mnogočemu je poseban, prostorno i vremenski ograničen svijet definiran kao ne-zbilja, ali nikako neozbiljan (Huizinga 1970). Prije svega igra je slobodna, odnosno, ona je sloboda (Huizinga 1970: 18). Igra nije ni ,pravi” ni „obični” život, već je smještena u jednu privremenu sferu. Ona je privremeni, emocijama obilježen svijet unutar svijeta svakodnevice. Kroz igru se ostvaruju ideali ljudskog postojanja: postojanje jasnih pravila, pravde, reda, zajedništva, zanesenosti, slobode i sl. Primjeri prikupljeni različitim metodološkim postupcima, koji će biti analizirani u ovome radu, potvrđuju osnovne karakteristike čovjekovog emotivnog doživljaja igre i njenog viđenja kao raja izgubljenog zajedno s djetinjstvom.

Povlačenje u odaje „dobrog starog djetinjstva” te izdvojeni i zaštićeni svijet u kojem dominira zajedništvo u igri zapravo je bijeg od promjena koje donosi sadašnjost i neuklapanja stečenih vizura s realizacijom društvenih i kulturnih okolnosti (cf. Holbrook 1993: 246). 


\title{
3.1. Igra i osjećaji zajedništva, slobode, izdvojenost
}

\begin{abstract}
Vedran i ja smo se igrali policajaca. Oboje smo bili detektivi. Svašta smo se igrali. Svi smo se igrali zajedno. Taj dio mi je ostao najviše u sjećanju, to zajedništvo, dječje zajedništvo. To je našu generaciju obilježilo. Kad danas djecu staviš u dvorište, oni se neće igrati. Ili će se potući ili će se igrati za sebe. Kultura je da im danas sve kupimo. Vrijednost igračke se izgubila, nije kakva ju mi poznajemo. Igrali smo se svi iz zgrade, i veliki i mali. Uopće nije bilo bitno koliko si star. Bili smo svi zajedno vani ispred zgrade i oko nje. A kad bi se prva ulična lampa upalila, ono, tko je prvi skužio, razglasio je i svi su morali doma. To je bilo pravilo. Sjećam se da je jednom jedan dječak iz susjedne zgrade dobio bejzbolsku palicu za rođendan. On je imao negdje trinaest godina, a mi negdje osam, devet. I nema veze to, svi smo po redu mogli lupiti lopticu s tim. To je bila zajednička igra. Ta palica nije bila samo njegova, nego sviju nas (autorcia: dvadesetšestogodišnjakinja).
\end{abstract}

Pričanjem o vlastitom djetinjstvu često proizvodimo osjećaj nostalgije, ispuštajući negativne sekvence i primisli, jednostavno poništavajući dosadu i običnost, ublažavajući razočarenja i bolna iskustva. Naše nam se djetinjstvo u usporedbi s današnjim generacijama čini ljepšim, intenzivnijim, nevinijim, a u pričama često naglašavamo zajedništvo u igri, bolju ljudsku koherenciju i interakciju, neprijetvornost i sveopće prihvaćanje jedni drugih. Šire promjene u kapitalističkim zemljama s implicitnim skupom vrijednosti, normi i stavova transformirale su strukturu društva i stilove življenja, a samim time i generirale drugačije aktualno djetinjstvo. Obrasci ponašanja koje modernitet prenosi na najmlađe generacije tobožnja su nužnost i težnja stalnoj mobilnosti, fleksibilnosti i robovanja vremenskim rokovima (Moran 2002: 168). Individualizacija društva (cf. npr. van Dülmen 2005) sa sobom je donijela i nove životne prioritete pojedinaca koji sve manje streme za zajedništvom. U fenomenološkom smislu, izmicanje granica između djetinjstva i odraslosti, ali i bitne promjene u društvu posljednjih desetljeća, proizvode konsternacijska gledišta i tjeskobni osjećaj, posežući ponovno za vlastitim, poznatim i memorijski „opipljivim” djetinjstvom. Tjeskoba nastala uslijed suočavanja s promjenama dovela je do proglašenja tzv. smrti djetinjstva (Postman 1982; cf. isto Buckingham 2000; Prout 2005), odnosno ideje o njegovom nestanku ili možda, najblaže rečeno, o njegovim korjenitim promjenama.

Prikupljena terenska građa, kao i svakodnevno sudjelovanje u pripovjedačkim aktivnostima, pokazali su da kada odrasli pripovijedaju o vlastitom djetinjstvu, kada komentiraju, svjedoče i iznose stavove o tom 
životnom razdoblju, vlastito djetinjstvo određuju u pravilu kao humanije, druženja tijekom djetinjstva označavaju kao bogatstvo, a igračke kao sredstva za neprestanu gradnju maštovitih svjetova slobode bez ikakvih ograničenja.

Reinterpretacija prošlosti koja omogućuje usporedbu današnjeg stanja s prijašnjim proizvodom je nezadovoljstvo tekućim zbivanjima, tjeskobom življenja i turbulentnih promjena. Stoga se kroz naraciju iznova modelira „unutarnje dijete”. Osjećaj odgovornosti, nužnost samokontrole i prilagodbe društvenoj stratifikaciji, kao i različitim ljudima, kroz naraciju se suprotstavlja sjećanju na nestašno, radoznalo, svijetu otvoreno dijete. Zbog toga se narativnim sredstvima poseže za vlastitom prošlosti koja u sadašnjosti izgleda privlačnom i spasonosnom.

Prikupljena građa pokazuje da udaljenost koju naracija pokušava obujmiti nije samo vremenska, odnosno da sjećanja na djetinjstvo i odraslost nisu samo vremenski udaljeni, već da važno mjesto u naracijama ima i prostorna udaljenost i izdvojenost dječje igre od prostora gdje se biva odraslom osobom. Dječja igra se u naracijama izdvaja iz prostora svakodnevnog življenja koji pripada odraslima čak i kada su fizičke udaljenosti male ili simboličke. Toposi kao što su „oko zgrade” ili „golemo dvorište dječjeg vrtića u blizini”, „na drvetu” funkcioniraju kao izolirana mjesta slobode bez uplitanja odraslih i ispreplitanja generacijskih perspektiva življenja.

Memorijski aspekt povratka u prošlost često ne podrazumijeva točno definirano vrijeme, nego obuhvaća kontinuiranu izdvojivost dječjeg iskustva u kojemu nema ograničenja i vremena ${ }^{4}$. Igračke kao objekti dječjeg interesa i sredstva gradnje fiktivnog svijeta nostalgične su poveznice i podsjetnici na (re)konstruirano vrijeme spontanosti i bezbrižnosti (cf. Moran 2002: 168).

Suvremenost je i inače nostalgičan prizvuk djetinjstva pojačala stvaranjem opsadne kontrole i manipulacije nad dječjim druženjima, aktivnostima i cjelokupnim življenjem. Aktivnosti djece kao što su igre na ulici, lutanja po vrtovima, dvorišne igre i okupljanja s vršnjacima sve su rjeđe aktivnosti u svakodnevici. Ritam slobodnog vremena kreiran je pod

${ }^{4} \mathrm{~S}$ tim u skladu pripovijeda se ono što je u kognitivnoj psihologiji prepoznato kao generičko ili opće pamćenje (Brewer 1986: 34; 1996: 19). 
nadzorom odraslih u svrhu modeliranja određenog profila budućeg odraslog ljudstva (cf. Moran 2002: 166). Spomenute su spoznaje suvremenog čovjeka uvjetujuće za nostalgične priče o vlastitom djetinjstvu kao i vrijednosne stavove o djetinjstvu danas.

\subsection{Pogled u čarobni ormar sjećanja: igračka kao jedan od okidača za nostalgičnu priču}

Konverzacijska cjelina koja slijedi snimljena je putem Skypea. Razgovarala je autorica teksta (Dimkov) s dvjema prijateljicama (dvadesetšestogodišnjakinje) koje su navođene na pričanje o sjećanjima na dječje igre, igračke i fotografije iz djetinjstva. Pritom je nastao spontani razgovor, što je rezultiralo iskazima nastalima u prirodnoj situaciji i omogućilo nov analitički uvid u oblikovanje nostalgične atmosfere, puteve u sjećanja i priče. Takav metodološki postupak omogućuje konverzacijski kontekst oslobođen krutosti strukturiranog intervjua i unaprijed osmišljenih pitanja s određenim ciljevima (cf. Marković 2012: 219).

Marijana: A jeste sačuvale neke igračke, onak, samo neke?

Sanja: Pa samo neke, ali imam, imam igračke. Ove lutke dvije što smo dobili Vedran i ja kad smo bili mali jako. E to sam ti htjela reći, imali smo velike lutke, to sam si sačuvala. Jedna je moja, sa smeđim očima, je li, moja je Ana. A druga je dečko sa plavim očima. I to je Ivan. S njima sam se ja igrala kuće. I doktora.

Marijana: Zakon!

Sanja: I one su još uvijek ovdje. Zapravo, mogla bih otvoriti ormar i vidjeti. Nisam dugo pogledala. Idem vidjeti, pa ću ti reć stvarno šta imam.

Marijana: Aaaa, kak lijepo.

(Nastavak razgovora nakon kratke pauze.)

Sanja: Evo me. Isuse Bože! (smijeh)

Marijana: Što??

Sanja: Isuse Bože. Gle ovo! Imam ruksak, Isuse Bože, sa baleta. Imam ruksak iz baletne škole. E, crni pravi ruksak. E, nosit ću ga, ozbiljno, najozbiljnije! Imam sačuvane, Isuse Bože, gle ovo!!!

Marijana: Hahaha!

Sanja: Imam češalj Pocahontas, koji sam dobila, zajedno sa ovaj, kak se zove, mmmm, ovaj, za neki rođendan sam dobila sapun u kutijici, i češalj Pocahontas. To ti je bilo za poklon tad. Imam dva novčanika, mala. E da imam rekete za badminton. I ove, loptice imam. Imam dva medeka, to su moja dva medeka.

Marijana: Aaaa, baš lijepo.

Sanja: I barbike, i Ken. Ovako. E, i bebe barbike i Ken. Hahaha! Gle ovo, imam psa od 
barbike! I odjeću. Isuse, moram priznati kak dobro zgledaju te barbike. Jedino ne znam kaj se s kosom desilo.

Marijana: Hahaha, svi su šišali te kose. Jeste vi ošišali bar jednu barbiku?

Sanja: Jesam. Al i kosa je preživjela, moram priznati. Ali žuća je, više nije plava, onak, pravo plava, bijelo plava. Al preživjela je... I u dobrom su stanju. I obučene su, gle, u haljine. To je bila moja omiljena igra iz djetinjstva, ja sam njima haljine radila od tkanine. A mama je imala hrpu tog kak je šivala, jel. Imam tu haljina. Imam tu, ajoj, a to mi je bio veliki šok za jednu barbiku. Znaš da smo uvijek dobivale one neke kineske. A onda je moj ujak meni kupio barbiku. A kupio mi barbiku koja je bila Sidney barbika. Ona Sidney kolekcija, znaš.

Marijana: Aha. Aha.

Sanja: E, a predivna je! A ja sam bila tak razočarana jer nije plava plava.

Marijana: Ajoj.

Sanja: A znaš kak lijepo zgleda! Isuse, i kosu ima... Aaaaa.

Marijana: Hahaha, to je legendarno.

Sanja: I torbe sam si sačuvala iz nekog razloga...

Marijana: Otvorila si svoj čarobni ormar iz djetinjstva!

Sanja: Aha! Imam Paju Paju, moraš ga vidjet. S njim sam spavala. Onda imam Anu, tu je još uvijek. Imam Ivana. Imam velikog medu Krešu kojeg sam dobila od svoje kume Dragice. Još uvijek je ovdje. Krešo. Sori, mama. To ti je to. Sve sam si to sačuvala.

Marijana: Aa, kak lijepo! A vidiš kolko dugo nisi već gledala to?

Sanja: Godinama. Ima valjda već deset godina sigurno. Nisam znala, uopće sam zaboravila da to imam. I torbu ovu.

Marijana: E sad tu torbu možeš iskoristit!

Sanja. Da, prvo ju moram malo provjetrit...

Marijana: Ali, nema veze. Dapače.

Sanja: Da, al barbike su me oduševile. Još uvijek su u stanju prvotnom. Da, da. Gle, imam i špangice na njima! Vid ovo! Gle, ima i cipele na nogama još uvijek!

Ksenija: Hahaha, da, ono, reakcija kad otvoriš ormar pa izvadiš stare stvari koje imaš! Marijana: Presuper!

Sanja: I kad se sjetiš što si izvodio s njima. A pala joj je noga, morala sam je lijepiti izgleda, joj... Ima i naušnice. Isuse Bože! Kak sam to sve zaboravila.

Marijana: Aa... Ali kako je to lijepo kad se sjetiš... Koje ushićenje!

Sanja: A ja sam imala i Kena što je bilo najbolje od svega.

Marijana: Ja nisam imala Kena. Ja sam imala žene, ono...

Sanja: Imala sam i mali češalj od te Sidney barbike s kojim sam mogla uvijat kosu, što je bilo fantastično. Idem sad joj probat uvijat kosu da vidim dal još funkcionira. Baš me zanima kak sam to radila... Čekaj... Češalj ima gore kao mali uvijač i barbiki se mogla uvijat kosa. A kažem ti ja sam bila tak jako razočarana zbog te barbike. A barbika je tolko fenomenalna, da ono... Čekaj, čekaj, da stvarno vidim ili sam si ja to umislila da sam mogla uviti... Aa, pa uvija joj se kosa! Ovo morate vidjeti!

Marijana: Hahaha.

Sanja: Uvija joj se kosa, najozbiljnije! Ono, Isuse Kriste, nisam si to umislila. Stvarno joj se uvija kosa.

Marijana: Hahaha. Ono, ko povratak iz budućnosti. 
Ksenija: U djetinjstvo, da...

Sanja: Al nema veze, idem joj uvijat kosu, hahaha. Možda jesam luda....

Marijana: Hahaha, sad će doć Vedran u sobu i past u nesvijest.

Sanja: Ali najozbiljnije, imam znači lutkicu koja je zapravo barbika od moje mame. I uopće ne izgleda ko barbika nego kao mala lutkica. I obučena je, molim lijepo, lijepo je obučena, moram istaknuti kreacije. Ima i cipele čak. Ima i cipele Ken, ali jedino od Kena, ništa nisam napravila s njim.

Marijana: A kaj s bebama, jesi njih sređivala?

Sanja: Je, ovu malu. E da se razumijemo, imam i psa. A gle obleku, sad mogu novu im obleku napravit.

Marijana: Hahaha, genijalno! Dala sam ti novi posao.

Sanja: Eto... vidiš kak je zabavno kad si me natjerala da otvorim svoj butik!

Marijana: Hahaha, i onda se pitaš zašto nismo ovo radili već godinama...

Sanja: Al kolko je to zabavno, gle, ne znam zašto smo mi to uopće zaboravili?!

Marijana: A je, jelda? A biti dijete u duši, to je tako lijepo.

Sanja: Idem joj napravit frizuru.

Marijana: Hahaha Ksenija, a ti gledaš tamo...

Ksenija: Ja ležim tu i maštam!

Marijana: Šta radiš?!

Ksenija: Maštam.

U ovom primjeru prvotno neizravni poticaj zazivanja prošlosti oblikovao se u uzajamno pripovijedanje, odnosno, uzajamne, pojedinačne reminiscencije djetinjstva koje imaju zajedničku poveznicu u kolektivnom pamćenju. U toj cjelini iznova prepoznajemo i osnovnu karakteristiku igre, a ona je stvaranje osjećaja zajedništva.

Iako su u navedenom primjeru memorijski prizivi stizali kao pojedinačne reminiscencije, zajedničkim snagama stvorila se riznica zajedničkih motiva, s kojima je svaka sudionica konverzacije imala iskustvo. Prošlo vrijeme na taj je način postalo utočišna lokacija s vrlo nepredvidljivom strukturom (cf. Boym 2001: 22). Samim time potencirala se pojava snažnog osjećaja nostalgije, utopijskog spektra koji je zadužen za fantaziranje prošlosti, s implikacijama ambivalentnosti, odnosno ponavljanja neponovljivog i materijalizacije nematerijalnog (cf. Boym 2001: 35). Balansirajući u takvom konceptu nostalgije, vidljivo je da ona sadrži mehanizam zavođenja i manipulacije, ali postojano opstaje kao neizmiciva nuspojava suvremene kulture.

Materijalni ostaci prošlosti, u ovom slučaju igračke, nose biljeg vremena i bez obzira na sadržajno nefunkcionalnu ulogu u sadašnjosti, ispunjavaju emotivne praznine zbog izgubljenog vremena i daju privid 
uhvatljivosti. Igračke možemo promatrati kao „ostavštinu” djetinjstva. Materijalni predmeti koji funkcioniraju kao ostavština u odrasloj dobi podatni su za upisivanje najrazličitijih značenja i dubokih emocija. Sugovornica je u prethodnom primjeru izdvojila najznačajnije igračke iz vlastitog djetinjstva, ali im je značenje pridodavala u trenutku pripovijedanja, a ona su se taložila cijelo vrijeme igraće nefunkcionalnosti predmeta. Narativni slijed prisjećanja doveo je do nastojanja da se uspomene potvrde i obnove emocionalni svjetovi kroz sačuvane objekte iz djetinjstva.

Otvaranje ormara i zadiranje na njegovo dno gdje leži torba s uspomenama projekcija je ponovnog ulaska u odmaklo vrijeme, diktirano usporenim ritmovima, u fazu, iz pripovjedne perspektive gledano, bezbrižnog života. U nastavku dijaloškog procesa, sugovornica vlastita sjećanja potiče pomoću sačuvanih predmeta i igračaka, tobožnjih svjedoka njezinog djetinjstva u koje bi se htjela vratiti. Ushićenom jezičnom ekspresijom emotivnog zadovoljstva pokazuje se istinitost žudnje i traganja za osobitim elementima koji nedostaju u poziciji odrasle osobe. Posezanjem za predmetima koji su obilježili brojne trenutke rekonstruira se vrijeme koje je neuhvatljivo (Stewart 1988: 228). Na taj način predmeti postaju ,produžena ruka" za obnavljanje (ne)svršenog procesa ontogeneze. Vremenski odmak koji je moćno sredstvo nostalgične priče pridonio je sugestivnom jačanju uspomena kroz materijalne ostatke koji dobivaju novu, neočekivanu estetsku dimenziju, ponovno im je vraćena, a često za potrebe nostalgične priče i ,izumljena” emotivna vrijednost. Igračke koje su do trenutka naracije bile dio svakodnevice, samorazumljivi kontinuitet i materijalni ostatak iz dječjeg vremena i prostora, u trenutku pripovijedanja postaju idealizirane, uljepšane, viđene refleksivnom nostalgijom (cf. Boym 2001: 161). Prijepor između ostavljene prošlosti i reminiscencije u sadašnjosti navodi na zaključak da izmaknuti objekt nikada nismo ni posjedovali, stoga ga niti u jednom trenutku ne možemo ni imati (cf. Moran 2002: 162), osim kroz priču, vlastiti konstrukt za ublažavanje boli i zazivanje transcendentnosti. Stoga sačuvani predmeti, iako često spremljeni na vizualno nepristupačnom mjestu, „u dnu ormara”, figuriraju kao spomenici trenutaka koji kao takvi nisu ni postojali. U narativnoj manifestaciji prisjećanja fragmentarni ostaci ne mogu prenijeti potpunu sliku niti doživljaja niti realističnost predmeta, ali sačuvani materijalni oblici koje često nazivamo uspomenama, omogućuju detaljističko obnavljanje njihove simbolike. Refleksivno 
putovanje u prostor i vrijeme djetinjstva kakvo je ostvareno u prethodnom primjeru, osobne je uspomene izronilo u sadašnjost pripovijedanja oslobađajući segmente povijesnosti, rekonstruirajući realnost, proizvodeći nostalgiju.

\subsection{Auto bez guma i balega kao igračke iz snova?}

Već smo u prethodnom primjeru vidjeli da nesavršenost materijalnog predmeta za igru, iz perspektive odraslog pripovjedača, nije ni izbliza narušila nostalgičan priziv njegove uporabe. Predmet je savršenim sredstvom nostalgičnih evokacija učinilo vrijeme koje je prošlo. U tom smislu otvorenim ostaje pitanje kako moć nostalgije može brisati, selektirati, prepravljati i falsificirati nedostatke prošlosti i njezinih materijalnih ostataka. Manipulaciju nostalgije primjećujemo i u drugim aspektima djetinjstva. Ta je manipulacija tako snažna da može uljepšati i činjenice kao što su siromaštvo i neimaština.

Dva primjera koja slijede svoj nostalgičan ton grade na nedostacima vremena o kojemu pričaju te nesavršene predmete u svojoj nostalgičnoj priči - koju, eksplicitno ili implicitno, stavljaju u opreku sa sadašnjošću prozivaju savršenim igračkama.

Imamo autiće u Vedranovoj sobi, a nemaju ni gume. Onda smo to odnijeli kod mene na posao i klinci ti se nisu htjeli s tim igrati. A mi smo se igrali bez obzira na to, nije nam smetalo (autorica: dvadesetšestogodišnjakinja).

Snježana: Nije bilo znači nekakvih igrački, jedino, znaš šta je balega?

Marijana: Balega?

Snježana: To ti je od konja izmet, konjski izmet, koji smo ti mi kad se osuši, natakneš na štap, hahaha, zapališ i onda ti, hahaha, trčiš po livadama, kužiš, hahaha, to ti je nama bio doživljaj, e... Moš mislit, čija neće past izdrži, ono, jel, ko najduže je zadrži, to su ti livade koje su ko stepenice napravljene i ti si to trebo trčat, to je bilo jedna od nama najzanimljivijih igri... Ne znam, tad u to vrijeme to je tako bilo, nisi imo nekakvih tu igrački, mada opet nije da se nije imalo... (autorica: četrdesetdvogodišnjakinja).

U posljednjem primjeru kazivačici je prisjećanje na trenutke igre s nesavršenim igračkama izazvalo radost i smijeh. Naglasak na neimanju igračaka naglašava i njezin stav o potpunoj nevažnosti „savršene” igračke za uspostavu čežnje za djetinjstvom. Ovakav oblik igre za kazivačicu 
argument je u korist teze o djetinjstvu kao vremenu slobode i nesputanosti.

Nasuprot idealiziranoj nostalgičnoj priči o vlastitom djetinjstvu u pravilu stoji priča kojom se komentira djetinjstvo danas, kvalitativno lošije od onog prošlog, s manje slobode, a više materijalnih resursa. U takvim je narativima izražena kritika i strah za budućnost vlastite djece. Pripovjedači svoje stavove u pravilu doživljavaju ozbiljno bez mogućnosti ironičnog odmaka prema vlastitoj pripovijesti i iskustvu (cf. Marković 2011). Poticaj za takvu priču je u obnavljajućem tipu nostalgije (cf. Boym 2001: 49).

Snježana: Sad šta djeca imaju to... Kad vidim Hanu, recimo, meni je... Ja mislim da sam bila sretnija. Ozbiljno! Nisi imo, stvarno nisi imo... Ali ja se ne sjećam da sam i za čim patila, da je meni šta trebalo... Tata donio tu barbiku iz Njemačke. Nije to bila ni barbika, to je bila neka lutka s pundžom, čovječe. Ali mi smo se zbog nje samo svađali. Znaš ono, meni je dobra, sestri, ono, samo bi se zbog nje svađali. Ali mislim da je bilo nama bolje u Hercegovini, gdje nisi imo. Što manje stvari, to je bolje. Ovo što djeca danas imaju, to je prešlo sve granice... Prešlo sve granice. I mislim da ne znaju uopće uživat... Jer ja vidim po Haninom odrastanju. Ona je još imala igračke i znala se zaigrat. Recimo, strašno je volila puzzle. Ali sad kad pogledam, ta djeca su na laptopu, ne znam, iphoni nekakvi. Dečkići s tim kojekavim x-menima, mislim da to uopće... Da je bilo bolje nama. Premda isto kad dođeš u Slavoniju ti vidiš da se ta djeca igraju, da još uvijek ima ono da se oni navečer igraju žmirke. Da, da, ima, ima tog, i ne znam... Ono, moja Hana se recimo volila s onim vodenim balonima igrat... Daleko je nama. Ja nisam recimo s ovim svim... Kud to sve ide, meni se to ne sviđa... Kažem, ja sam igrom slučaja odrastala u takvom okruženju, s dvije i pol godine do sedme godine. Baš ono gdje nisi imao. Moja prva igračka bila je kad sam došla u Slavoniju... I u svakom pogledu ne žalim za ničim. Ne žalim za ničim i volila bih da su ovdje vremena malo drukčija. Jer ja vidim kolko djeca... Pokvari to sve. I Branka isto, Branka je odrastala kod bake... Vidi po svojoj Lani da ona previše ima i razmažena i... I šta god daš, ti ne znaš što ćeš djetetu za rođendan pokloniti. Jer ono, već sve ima. Znaš ono, ja Hani nisam nešto previše, ali mi je bilo žao pa bih kupila onaj stol za biljar, igru ovakvu onakvu, bez veze. Dao si novce i poslije vidiš da je to uopće nepotrebno. Da bi nju više možda razveselila neka sitnica... Al eto, stalno misliš da joj malo daješ, ne daješ joj dovoljno... Al kad pogledam sebe, mislim da je bilo bolje... Evo, sad kad sam bila u Hercegovini sjetila sam se tih igri naših. Ali je to meni bilo... Djeca su isto radila, ti si moro isto u polje ići, i krave čuvati... I krompir vadit... Recimo, ja sam obožavala ono kad traktor ide sijeno skupljat... Al to je bilo zanimljivo jer si znao da to moraš. Ili žito kupiti... Meni je to bilo puno bolje i ja bi volila da se opet kod nas to nešto promijeni... A ne znam šta ta djeca danas mogu iz djetinjstva pamtit... Moja Hana je rođendane slavila u McDonaldsu, slavila je u nekakvim igraonicama, slavila je u onome gdje su bili kojekakvi sportovi, onaj đamping, one gluposti... Ona će po tom pamtit djetinjstvo... I kakve poklone je dobila (autorica: četrdesetdvogodišnjakinja). 
U navedenom primjeru osuda stalne težnje za posjedovanjem i materijalizmom isprepletena je s nostalgičnom pričom o vlastitom djetinjstvu koje je u sjećanju pripovjedačice u vrijednosnom smislu bolje, kvalitetnije, slobodnije, sadržajnije, iako oskudno materijalnim dobrima. Ekonomske i društvene promjene za pripovjedačicu su bile okidač narativa o udaljavanju djetinjstva današnjice od idealiziranog djetinjstva prošlosti.

Djeca su danas veliki potrošači. Vrlo su utjecajni kada su u pitanju oblici trošenja obiteljskog novca te vrlo često određuju brojnost i stanje vlastitog carstva igračaka, tehnoloških uređaja i sl. Pripovjedačica prethodnoga primjera problematizira usmjerenost djeteta današnjice na materijalne predmete, ali istovremeno opaža svoju vlastitu podvojenost jer istovremeno vapi za vremenom koje je nepovratno prošlo i vrijednostima koje ju vezuju za razdoblje vlastitog djetinjstva, a istovremeno, kako i primjećuje, postupa kontradiktorno u odgoju vlastitog djeteta jer je i sama podlegla imperativu posjedovanja kao uvjetu zadovoljstva i sreće svoga djeteta. Iščitavajući višeslojnost narativnog i prisjećajnog procesa u pojedinom kontekstu pripovijedanja pokazuje se da nostalgija u narativnom diskursu jača porastom potrebe za povratkom u vrijeme vlastitog djetinjstva i bijegom od promjena. Unatoč tome što prisjećajno i narativno obnavljanje prošlih vremena karakterizira kontekstualan i parcijalan proces sjećanja, pripovjedači nostalgične priče svoj iskaz često tretiraju kao objektivan i cjelovit (cf. Boym 2001: 161). Ideja da je djetinjstvo u prošlosti bilo bolje, čak i unatoč neimaštini koju vlastitoj djeci ne želimo priuštiti, pokazuje da u narativima kao što je prethodni, nostalgiju treba promatrati „kao čežnju za društvenim konceptom djetinjstva tzv. zapadnog kruga, čije su (...) današnje dominantne odrednice bezbrižnosti, zaigranosti, nevinosti u opreci s neumoljivom zbiljom odraslih" (Marković 2012: 317). Paradoksalan je trud omogućavati vlastitoj djeci ljepši život s konačnim rezultatima koji moralno „užasavaju”, a istodobno žaliti za vremenom čiji potencijali i resursi nisu za njih dostatni (cf. Boym 2001: 74). Time se samo potvrđuje, s jedne strane, da je sjećanje oblik zaborava te da je nostalgična priča potencijalno utočište za sve one koji se teško suočavaju s nepredvidivim mijenama kulturnih krajolika u kojima živimo (cf. Moran 2002: 157).

Zaključno, stvarnost koju nostalgična priča nastoji opisati nikada nije ni postojala, osim kao priča, te kvalitativne ocjene djetinjstva nekada i danas u svakodnevici nužno ostaju u sferi emocijama nabijene priče, a ne 
nekog činjeničnog, argumentiranog promišljanja promjena koje djetinjstvo prolazi od trenutka njegova „otkrića” do danas.

O emocionalnoj važnosti sjećanja na svijet igre i igračaka kao materijalnih predmeta najbolje svjedoči činjenica da su nostalgične priče koje ih tematiziraju derivirane iz autobiografskog pamćenja koje je spremište iznimno malog broja proživljenih iskustava tijekom djetinjstva, odnosno spremište „krpica sjećanja” (Bošković-Stulli 2007) iz djetinjstva koje je mahom prekriveno zaboravom.

Iako je ovim radom uhvaćen tek malen, gotovo beznačajan dio svakodnevice, razvidno je koliko je u tom djeličku naših života i života naših sugovornika bilo važno posredstvom priče ili kroz nju komunicirati emocije potaknute sjećanjem na, po mnogočemu poseban, svijet igre i/ili potaknute ponovnim uvidom u materijalne ostatke jednog životnog razdoblja. Igra kao aktivnost $u$ kojoj se ostvaruju ideali ljudskog postojanja i kao aktivnost koja u predodžbenom svijetu velikim dijelom definira djetinjstvo, oživljena je u emotivno nabijenim narativnim isječcima koji u konačnici pokazuju da, bez obzira na sadržajno nefunkcionalnu ulogu igračaka u sadašnjosti, sjećanja koja one potiču u odrasloj dobi ispunjavaju emotivne praznine nastale promjenama u suvremenosti i onima koje donosi ontogeneza.

\section{Literatura}

Bošković-Stulli M., 2007, Priče iz moje davnine, Zagreb.

Boym S., 2001, The Future of Nostalgia, New York.

Braid D., 1996, Personal narrative and experiential meaning, „Journal of American Folklore" br. 109, str. 5-30.

Brewer W., 1986, What is autobiographical memory?, u: Autobiographical Memory, ur. D.C. Rubin, Cambridge, str. 25-49.

Brewer W., 1996, What is recollective memory?, u: Remembering Our Past. Studies in Autobiographical Memory, ur. D.C. Rubin, Cambridge, str. 19-66.

Buckingham D., 2000, After the Death of Childhood. Growing Up in the Age of Electronic Media, Cambridge.

Gulin Zrnić V., 2006, Domaće, vlastito i osobno: Autokulturna defamilijarizacija, u: Etnologija bliskoga. Poetika i politika suvremenih terenskih istraživanja, ur. J. Čapo Žmegač, V. Gulin Zrnić, G.P. Šantek, Zagreb, 73-95.

Hastrup K., 1992, Writing ethnography: state of the art, u: Anthropology and Autobiography, ur. J. Okely, H. Callaway, London-New York, str. 116-133. 
Holbrook B.M., 1993, Nostalgia and Consumer Preferences: Some Emerging Pattern of Consumer Tastes, „The Journal of Consumer Research” br. 20, str. 245-256.

Huizinga J., 1970, Homo ludens: o podrijetlu kulture u igri, prev. A. Stamać, Zagreb.

LeBlanc R.D., 1999, Food, Orality, and Nostalgia for Childhood: Gastronomic Slavophilism in Midnineteenth-Century Russian Fiction, „Russian Rewiev” br. 58, str. 244-267.

Marković J., 2010a, Arhiviranje života (djetinjstva) izbliza. Neke refleksije o problemima pohrane i transkripcije terenskih snimki, „Etnološka tribina” br. 33, str. 57-69.

Marković J., 2010b, Pričanja o djetinjstvu i srodni koncepti: „Velike” i/ili „male” priče, „Narodna umjetnost. Hrvatski časopis za etnologiju i folkloristiku” br. 47, str. 51-76

Marković J., 2011, Brandovi, djetinjstvo i nostalgija, u: Kulturna dediščina industrijskih panog. 11. Vzporednice med slovensko in hrvaško etnologijo, ur. A. Černelič Krošelj, Ž. Jelavić, H. Rožman, Ljubljana, str. 350-357.

Marković J., 2012, Pričanja o djetinjstvu: život priča u svakodnevnoj komunikaciji, Zagreb.

Moran J., 2002, Childhood nostalgia in contemporary culture, „European Journal of Cultural Studies" br. 5, 155-173.

Okely J., 1992, Anthropology and autobiography. Participatory experience and embodied knowledge, u: Anthropology and Autobiography, ur. J. Okely, H. Callaway, London-New York, str. 1-28.

Postman N., 1982, Disappearance of Childhood, New York.

Prout A., 2005, The Future of Childhood. Towards the Interdisciplinary Study of Childhood, London-New York.

Stewart K., 1988, Nostalgia - A Polemic, „Cultural Antthropology” br. 3, str. 227-241.

Stewart S., 2003, On Longing: Narratives of the Miniature, the Gigantic, the Souvenir, the Collection, Durham.

Tulving E., 1972, Episodic and semantic memory, u: Organization of Memory, ur. E. Tulving, W. Donaldson, New York, str. 382-402.

Winnicott D.W., 2004, Igra i stvarnost, Zagreb.

Van Dülmen R., 2005, Otkriće individuuma 1500.-1800. Golden marketing - Tehnička knjiga, Zagreb. 